\title{
Effect of steroid- and inhibin-free ovine follicular fluid on ovarian follicles and ovarian hormone secretion
}

\author{
B. K. Campbell ${ }^{1, *}$, H. M. Picton ${ }^{1}$, G. E. Mann ${ }^{1}$, A. S. McNeilly ${ }^{2}$ and \\ D. T. Baird ${ }^{1}$
}

${ }^{1}$ University of Edinburgh Department of Obstetrics and Gynaecology; and ${ }^{2} M R C$ Reproductive Biology Unit, Centre for Reproductive Biology, 37 Chalmers Street, Edinburgh EH3 9EW, UK

\begin{abstract}
Summary. Treatment of ewes with steroid-free ovine follicular fluid (oFF) during the follicular phase of the oestrous cycle results in the immediate inhibition of the ovarian secretion of oestradiol, inhibin and androgens. An experiment was conducted to determine whether this effect of oFF was due to inhibin, or to direct inhibition of ovarian function by other factors in oFF.

Eight ewes in which the left ovary and vascular pedicle had been autotransplanted to a site in the neck were studied during the breeding season. Luteal regression was induced in all animals by injection of cloprostenol (100 $\mu \mathrm{g}$ i.m.; PG) on Day 10 of the luteal phase. The animals were divided into two groups $(n=4)$ and treated with either

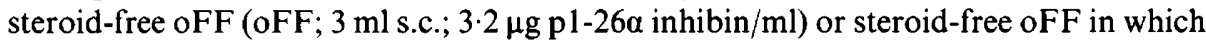

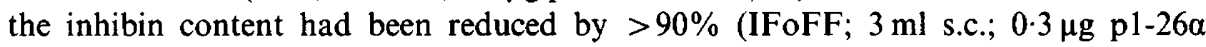
inhibin/ml) by affinity chromatography, 24 and $36 \mathrm{~h}$ after PG. Samples of ovarian and jugular venous blood were collected at (i) intervals of $4 \mathrm{~h}$ from $16 \mathrm{~h}$ before until $120 \mathrm{~h}$ after PG and (ii) intervals of $10 \mathrm{~min}$ from 48 to $52 \mathrm{~h}$ after injection of $\mathrm{PG}$ to investigate the pattern of pulsatile secretion of ovarian hormones. All ewes had previously been monitored during a normal PG-induced follicular phase.
\end{abstract}

Injection of oFF resulted in an increase $(P<0.05)$ in the concentration of inhibin in jugular venous plasma and a profound $(P<0.001)$ and prolonged decrease in the peripheral concentration of follicle-stimulating hormone (FSH). Injection of IFoFF had no significant effect on peripheral concentrations of inhibin or FSH in the first $24 \mathrm{~h}$ after treatment; thereafter inhibin concentrations fell $(P<0.01)$ progressively until $40 \mathrm{~h}$ and then increased $(P<0.01)$ until $72 \mathrm{~h}$ after treatment. In both treatment groups, however, within $24-36 \mathrm{~h}$ of treatment the concentration of FSH increased 5-10-fold $(P<0.001)$ to a peak that occurred within $48-60 \mathrm{~h}$ and then declined to basal concentrations within $72-84 \mathrm{~h}$ of treatment. The concentration of luteinizing hormone $(\mathbf{L H})$ in jugular venous plasma increased in both groups after treatment $(P<0.01)$, although the rise after injection of oFF only started after $24 \mathrm{~h}$. Thereafter, there was a progressive increase in the concentration of $\mathrm{LH}$, peaks occurring $48-60 \mathrm{~h}$ after treatment. The preovulatory $\mathrm{LH}$ surge was delayed by $\sim 48 \mathrm{~h}$ in both groups of ewes, being detected at $114 \pm 5 \mathrm{~h}$ and $110 \pm 4 \mathrm{~h}$ after PG in ewes treated with oFF and IFoFF, respectively $(P<0.001)$. The effects of oFF and IFoFF on ovarian hormone secretion were similar, the secretion rate of oestradiol, androstenedione and inhibin beginning to decline within $8 \mathrm{~h}$ of the first injection $(P<0.001)$. The rate of decrease was more marked for the steroids, a mean nadir of $<1 \mathrm{ng} / \mathrm{min}$ being reached within $12-24 \mathrm{~h}$ of treatment whereas inhibin secretion did not reach a nadir until $36-44 \mathrm{~h}$ after treatment.

*Present address: Division of Animal Production, PO Box 239, Blacktown, NSW 2148, Australia. 
Androstenedione secretion began to increase $(P<0.05)$ within $24 \mathrm{~h}$ of treatment whereas inhibin and oestradiol secretion did not begin to increase significantly $(P<0.05)$ until $4860 \mathrm{~h}$ after treatment. Generally, ovarian hormone secretion tended to increase until $72 \mathrm{~h}$ after treatment, after which mean secretion rates reached a plateau. In ewes treated with oFF or IFoFF the episodic secretion of oestradiol and inhibin was markedly suppressed and the amplitude of androstenedione pulses reduced, although the amplitude of $\mathrm{LH}$ pulses was greater than in normal untreated ewes. Injection of oFF or IFoFF caused a marked decline $(P<0.01)$ in the number of large follicles within $48 \mathrm{~h}$ of treatment and, concomitant with the rebound release of FSH, an increase $(P<0.01)$ in the number of small follicles/ovary. By $96 \mathrm{~h}$ after treatment, the number of large follicles/ewe had increased $(P<0.05)$ to pretreatment levels, concomitant with a decline $(P<0.05)$ in the number of small follicles. In individual animals, changes in gonadotrophin concentrations, ovarian hormone secretion rates and ovarian follicle populations were temporally related.

We conclude that oFF contains a factor that acts directly on the ovary to induce atresia of large preovulatory follicles and results in immediate suppression of ovarian inhibin, oestradiol and androstenedione secretion. The lack of feedback by ovarian hormones results in a rebound release of $\mathrm{FSH}$, which stimulates the growth of ovarian follicles, and the re-establishment of ovarian hormone secretion and normal cyclicity.

Keywords: follicle-stimulating hormone; inhibin; oestradiol; androgen; follicular fluid; sheep

\section{Introduction}

Follicular fluid is a rich source of the ovarian hormone inhibin (Leversha et al., 1987), which, with oestradiol, controls the concentration of follicle-stimulating hormone (FSH) in the peripheral circulation (Martin et al., 1988; Mann et al., 1989, 1990). It is now well documented that repeated treatment of ewes with steroid-free follicular fluid during either the luteal (Wallace \& McNeilly, 1985; Wallace et al., 1985) or follicular phase (McNeilly, 1984, 1985; Henderson et al., 1986) of the oestrous cycle results in an initial depression of FSH followed by a rebound release of FSH after the cessation of treatment. If follicular fluid administration is stopped either before (Wallace \& McNeilly, 1985; Wallace et al., 1985) or within $24 \mathrm{~h}$ (Henderson et al., 1988) of the induction of luteolysis, ovulation occurs at the normal time. In contrast, treatment of ewes with follicular fluid in the late follicular phase, for more than $24 \mathrm{~h}$ after induction of luteolysis, results in a delay in ovulation (McNeilly, 1984, 1985; Henderson et al., 1986, 1988). We have recently confirmed and extended these observations to show that treatment of ewes with steroid-free ovine follicular fluid (oFF) during the late follicular phase of the oestrous cycle, 24 and $36 \mathrm{~h}$ after induction of luteolysis, results in marked suppression in the ovarian secretion of oestradiol, androstenedione, testosterone and inhibin (Baird et al., 1990a). The loss and eventual re-establishment of inhibitory feedback offers an explanation for the transient increase in peripheral concentrations of FSH after treatment with follicular fluid. Given the large body of data which supports a pivotal role for FSH in the control of follicular development (McNeilly et al., 1990), the results of these experiments suggest that treatment of ewes with follicular fluid results in inhibition of follicular development (McNatty et al., 1985; Wallace et al., 1986), which can be attributed to the resulting depression in FSH secretion. The dominant follicle appears to maintain a dependence on FSH; suppression of its development during the late follicular phase, after selection has occurred, denies the animal sufficient time to compensate, resulting in delayed ovulation (McNatty et al., 1982; Tsonis et al., 1984).

Although the inhibition of ovarian secretion caused by oFF can be attributed to FSH, the magnitude and acuteness of the inhibitory effects of oFF (Baird et al., 1990a) suggest that other 
factors in oFF may act directly on the ovary to inhibit follicular growth (reviews: Hsueh et al., 1984; Ireland, 1987; Tonetta \& diZerega, 1989). Cahill and co-workers have reported that steroidfree oFF prevented follicular growth in both normal (Cahill et al., 1985) and hypophysectomized ewes given pregnant mares' serum gonadotrophin (PMSG) (Cahill, 1984). Immunization of ewes against partially purified follicular fluid increases ovulation rate in sheep without consistent increases in plasma FSH concentrations (Henderson et al., 1984; Cummins et al., 1986; Al-Obaidi et al., 1987), suggesting that immunization may be directed against inhibitors of follicle growth. A heat- and trypsin-labile protein, named follicle regulatory protein (FRP), isolated from porcine follicular fluid, has been shown to inhibit follicular growth in rats and monkeys in vivo and FSHinduced differentiation of porcine granulosa cells in vitro (Ono et al., 1986). In addition, epidermal growth factor (EGF), which is produced by the theca (Skinner et al., 1987; Skinner \& Coffey, 1988) and is present in porcine follicular fluid (Hsu et al., 1987), inhibits follicular growth (Radford et al., 1987) and the secretion of oestradiol (Scaramuzzi et al., 1988) and inhibin (Murray et al., 1989) in vivo. Furthermore, inhibin inhibits FSH-stimulated oestradiol production in vitro, suggesting an intra-ovarian role for this hormone (Ying et al., 1986; Tonetta \& diZerega, 1989).

The present experiment examined the effect of either steroid-free oFF or inhibin- and steroidfree oFF (IFoFF) on ovarian follicle growth and hormone secretion, to determine whether the suppression of ovarian hormone secretion by oFF observed previously (Baird et al., 1990a) was due to inhibin-induced suppression of jugular venous concentrations of FSH or to direct inhibition of ovarian function by factors in oFF.

\section{Materials and Methods}

Experimental animals. Eight Merino $\times$ Finnish Landrace ewes, in which the left ovary and vascular pedicle had been autotransplanted to a site in the neck and the other ovary had been removed, were studied during the breeding season (February: Goding et al., 1967). The animals were housed under cover with natural lighting conditions at the Institute of Animal Physiology and Genetics Research, Edinburgh Field Station, Dryden, Roslin, Midlothian, UK. During blood sampling, the animals were placed in metabolism crates in a temperature-controlled room $\left(11-15^{\circ} \mathrm{C}\right)$. As the corpus luteum persists in ewes with ovarian autotransplants, to synchronize oestrous cycles 2 injections of cloprostenol, a potent analogue of prostaglandin F-2 $\alpha$ (PG; $100 \mu \mathrm{g}$ i.m.; Estrumate: ICI plc, Macclesfield, Cheshire, UK), were given 14 days apart. On the day before the start of blood sampling, both jugular veins were cannulated, the catheter on the side of the ovary being advanced so that its tip lay opposite the ovarian vein (Collett et al., 1973).

Preparation of follicular fluid. Steroid-free oFF was prepared as described previously (Baird et al., 1990a) and contained $3235 \mathrm{ng}$ inhibin/ml (pl-26a) and had a bioactivity of $8076 \mathrm{U} / \mathrm{ml}$ (Tsonis et al., 1986).

The IFoFF was prepared by affinity chromatography; $6 \mathrm{ml}$ of serum from a sheep immunized against the $1-26 \alpha-$ subunit of porcine inhibin conjugated to ovalbumin (S55; McNeilly et al., 1989) was treated with 25 and $50 \%$ solutions of saturated ammonium sulphate and the precipitate was resuspended in $10 \mathrm{ml}$ of coupling buffer $(0 \cdot 1 \mathrm{M}$ $\left.\mathrm{NaHCO}_{3}, 0.5 \mathrm{M}-\mathrm{NaCl}, \mathrm{pH} 8.3\right)$. Following swelling and washing in $1 \mathrm{mM}-\mathrm{HCl}(200 \mathrm{ml} / \mathrm{g}$ dry gel) and equilibration with coupling buffer $(10 \mathrm{ml} / \mathrm{g}$ dry gel), $15 \mathrm{~g}$ of $\mathrm{CNBr}$-activated Sepharose 4B (Pharmacia, Uppsala, Sweden) was allowed to mix with the antibody preparation overnight at room temperature. The gel was then washed with $0 \cdot 2 \mathrm{M}$ glycine for $2 \mathrm{~h}$ at room temperature, followed by 5 alternate washes with $0.1 \mathrm{M}$ sodium acetate, $0.5 \mathrm{M}-\mathrm{NaCl}, \mathrm{pH} 4$, and coupling buffer. The gel was then washed with $50 \mathrm{~mm}$ Tris buffer, $\mathrm{pH} 7.4$, and poured into a $2.5 \times 45 \mathrm{~cm}$ column (SR 25/45: Pharmacia, Uppsala, Sweden). Following elution of the void volume, $100 \mathrm{ml}$ oFF was run circuitously on the column for $24 \mathrm{~h}$. The IFoFF was then frozen until used. Following treatment, the inhibin content of the oFF had been reduced by $\geqslant 90 \%$ to $259 \mathrm{ng}$ inhibin/ml $(\mathrm{pl}-26 \alpha)$ with a bioactivity of $832 \mathrm{U} / \mathrm{ml}$.

Experimental design. Luteal regression was induced in all animals by injection of cloprostenol (100 $\mu \mathrm{g}$ i.m.; PG) on Day 10 of the luteal phase. The animals were treated with either steroid-free oFF ( $3 \mathrm{ml} \mathrm{s.c.;} n=4)$ or steroid-free IFoFF ( $3 \mathrm{ml} \mathrm{s.c.;} n=4)$ in the early follicular phase, 24 and $36 \mathrm{~h}$ after the induction of luteolysis. Samples of ovarian $(5-7.5 \mathrm{ml})$ and jugular $(4 \mathrm{ml})$ venous blood were collected at 4-h intervals from $20 \mathrm{~h}$ before until $120 \mathrm{~h}$ after induction of luteolysis by injection of PG. Blood samples were also collected at 10-min intervals from 48 to $52 \mathrm{~h}$ after injection of PG in order to examine the pulsatile patterns of secretion of ovarian hormones and gonadotrophins. Ovarian blood flow was measured by timing the collection of ovarian venous blood and the ovarian secretion rates of oestradiol, androstenedione and inhibin were calculated after correcting for the haematocrit (Collett et al., 1973) and peripheral concentrations of hormone (inhibin only). Subsequent luteal function was monitored by daily collection of jugular venous blood samples for 11 days after PG. 
Ovarian scanning procedure. The ovarian follicle population was examined daily using a combined-sector, realtime, ultrasound scanner (DSL 300) with a sector $7.5 \mathrm{MHz}$ transducer probe (Diagnostic Sonar, Kirkton Campus, Livingstone, UK). The area of skin over the ovary was clipped, scanning gel (Siel Sound Gel, Siel Imaging Equipment Ltd, Aldermasten, Berkshire, UK) applied and the animal constrained with a head halter. On occasion, additional manual restraint was necessary to hold the animal still. The ovary was scanned in horizontal and vertical planes. The diameter of the antral cavity and position of all follicles $>2 \mathrm{~mm}$ in diameter in the medial-lateral, dorsal-ventral and cranial-caudal planes was noted.

Hormone assays. Plasma concentrations of ovine LH and progesterone (McNeilly \& Fraser, 1987; McNeilly et al., 1986), oestradiol (Baird et al., 1981), androstenedione (Campbell et al., 1990a), FSH (Campbell et al., 1989) and 1-26a-subunit of inhibin (McNeilly et al., 1989) were determined using previously described radioimmunoassays. The sensitivity of the assays for LH, FSH, progesterone, oestradiol, androstenedione and inhibin were $0.2 \mathrm{ng}$ (NIH-LH$\mathrm{S} 18) / \mathrm{ml}, 0.3 \mathrm{ng}$ (NIAMDD-FSH-RPl) $/ \mathrm{ml}, 120 \mathrm{pg} / \mathrm{ml}, 120 \mathrm{pg} / \mathrm{ml}, 50 \mathrm{pg} / \mathrm{ml}$ and $35 \mathrm{pg} / \mathrm{ml}$, respectively. The intra- and interassay coefficients of variation were $<15 \%$.

Statistical analysis. The normal pattern of pituitary and ovarian hormone secretion following PG-induced luteolysis in the animals included in this experiment had been previously determined (see Campbell et al., 1990a, b; Baird et al., 1990a) and much of these data have not been replicated here. Statistical analysis of hormonal profile data was conducted within treatment groups on the effect of time on the pattern of hormone secretion before and after treatment, by repeated sample analysis of variance (ANOVA) in conjunction with Duncan's multiple range test. Because of the large variation in values within and between animals within treatment groups, all hormonal profile data were subjected to $\ln \times$ transformation before analysis. The preovulatory LH surge was defined to have occurred when at least 2 consecutive samples with $>20 \mathrm{ng} \mathrm{LH} / \mathrm{ml}$ were detected. Times from PG to the LH surge were compared by unpaired $t$-test using the flock average $(58 \pm 2 \mathrm{~h}$ ) as a basis for comparison.

The parameters of pulsatile hormone secretion were determined using the Munro pulse analysis program (Elsevier, Biosoft, UK). For pulsatile ovarian secretion, variations observed at secretion of $<1 \mathrm{ng} / \mathrm{min}$ were not considered to be pulses. The effect of treatment on pulsatile secretion was made by one-way ANOva in conjunction with Duncan's multiple range test. As a basis for comparison, pulse data from the same group of ewes determined at the same time from PG-induced luteolysis were used (Campbell et al., 1990b; Baird et al., 1990a). Because of the large variation in pulse intervals between treatment groups, these data were subjected to $\ln \times \operatorname{transformation}$ before analysis. Pulse amplitude and nadir were analysed untransformed.

The effect of oFF treatment on numbers of follicles was determined by repeated sample analysis of variance following $\sqrt{ }(x+0 \cdot 5)$ transformation due to the presence of zeros in these data.

\section{Results}

\section{Hormone patterns in animals given steroid-free oFF or IFoFF}

Jugular venous progesterone. In both groups of ewes, the concentration of progesterone in jugular venous plasma declined $(P<0.001)$ after injection of $P G$ and was undetectable for the remainder of the experimental period (data not shown). Both groups had $>1 \mathrm{ng}$ progesterone $/ \mathrm{ml}$ by 11 days after PG.

Jugular venous inhibin. Induction of luteolysis with PG had no significant effect on the concentration of inhibin in jugular venous plasma in either treatment group. Injection of oFF resulted in an increase $(P<0.05)$ in the concentration of inhibin, which reached a peak within $4-8 \mathrm{~h}$ of administration (Fig. 1). Peripheral concentrations of inhibin remained high $(P<0.05)$ until $24 \mathrm{~h}$ after the first oFF injection and thereafter remained relatively constant. In contrast, injection of IFoFF had no significant effect on the concentration of inhibin in the first $24 \mathrm{~h}$ after treatment; thereafter, inhibin concentrations fell $(P<0.01)$ progressively until $40 \mathrm{~h}$ after treatment and then increased $(P<0.01)$ until $72 \mathrm{~h}$ after treatment (Fig. 1$)$.

Jugular venous FSH and $\mathbf{L H}$. After the injection of $\mathrm{PG}$, the concentration of FSH decreased $(P<0.001)$ in both groups of ewes (Fig. 2). Within $4 \mathrm{~h}$ of the first injection of oFF, the peripheral concentration of FSH had begun to decrease $(P<0.001)$, reaching a nadir of $\sim 1 \mathrm{ng} / \mathrm{ml}$ within 12 $16 \mathrm{~h}$ of treatment (Figs $2 \& 3$ ). In contrast, injection of IFoFF had no significant effect on FSH concentrations in the $24 \mathrm{~h}$ after injection (Figs $2 \& 4$ ). In both treatment groups, however, within $24-36 \mathrm{~h}$ of treatment the concentration of FSH increased 5-10-fold $(P<0.001)$ to a peak that occurred within $48-60 \mathrm{~h}$ of treatment and then declined to normal within $72-84 \mathrm{~h}$ of treatment (Figs 2, 3 \& 4). 


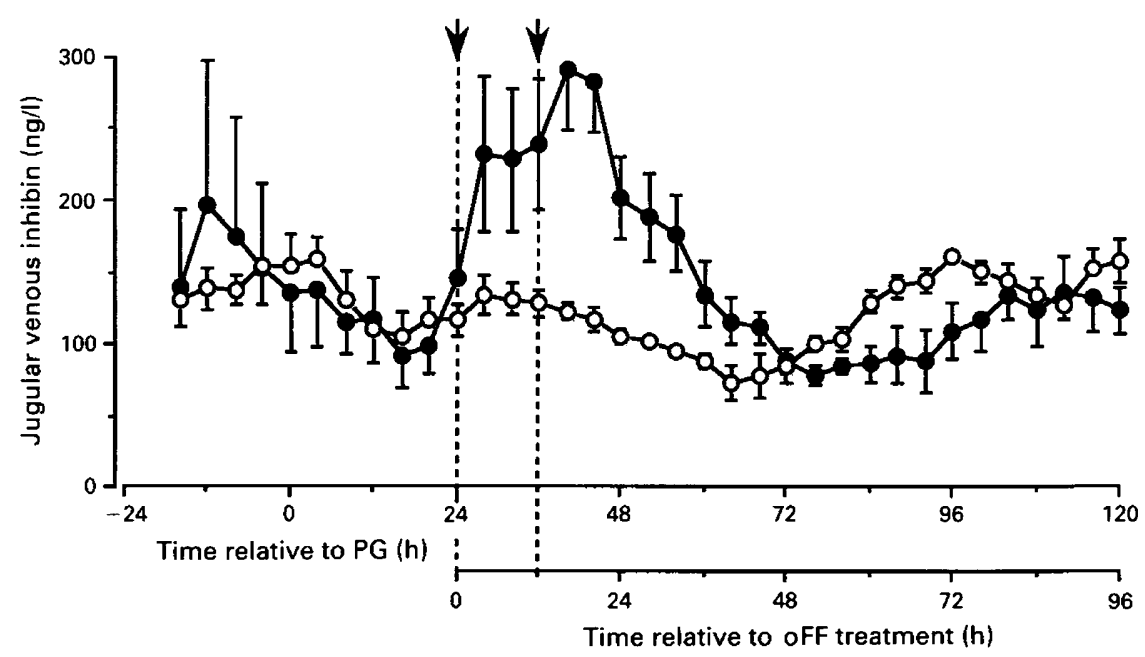

Fig. 1. Mean ( \pm s.e.m.) concentrations of inhibin in jugular venous plasma from ewes which received 2 injections (arrows) of either steroid-free ovine follicular fluid (oFF) $(0 ; n=4)$ or steroid- and inhibin-free oFF $(O ; n=4) 24$ and $36 \mathrm{~h}$ after the induction of luteolysis with cloprostenol (PG) on Day 10 of the luteal phase.

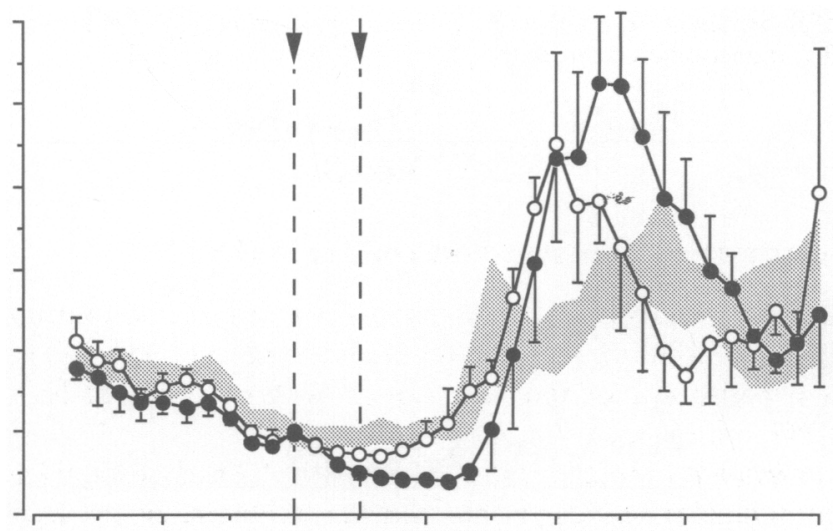

Fig. 2. Mean ( \pm s.e.m.) concentrations of follicle-stimulating hormone (FSH) in jugular venous plasma from ewes which received 2 injections (arrows) of either steroid-free ovine follicular fluid $(\mathrm{oFF})(\odot ; n=4)$ or steroid- and inhibin-free oFF $(O ; n=4$; arrows $) 24$ and $36 \mathrm{~h}$ after the induction of luteolysis with cloprostenol (PG) on Day 10 of the luteal phase. Shaded area represents the concentrations of FSH (mean \pm s.e.m.) in the same group of untreated ewes after PG-induced luteolysis ( $n=11$; Baird et al., 1990a; Campbell et al., 1990b), data expressed as a percentage of the concentration of FSH $24 \mathrm{~h}$ after PG.

The concentration of LH in jugular venous plasma increased $(P<0.01)$ in the first $24 \mathrm{~h}$ after treatment in ewes given IFoFF, but in ewes given oFF the rise was delayed until $24 \mathrm{~h}$ after treatment (Figs 3 \& 4). Thereafter, LH concentrations in ewes treated with oFF or IFoFF continued to increase, exhibiting a profile similar to that described for FSH (Figs 3 \& 4). The preovulatory LH surge was delayed by $\sim 48 \mathrm{~h}$ in both groups of ewes, being detected $114 \pm 5 \mathrm{~h}$ and $110 \pm 4 \mathrm{~h}$ after PG in ewes treated with oFF or IFoFF, respectively $(P<0.001)$. 


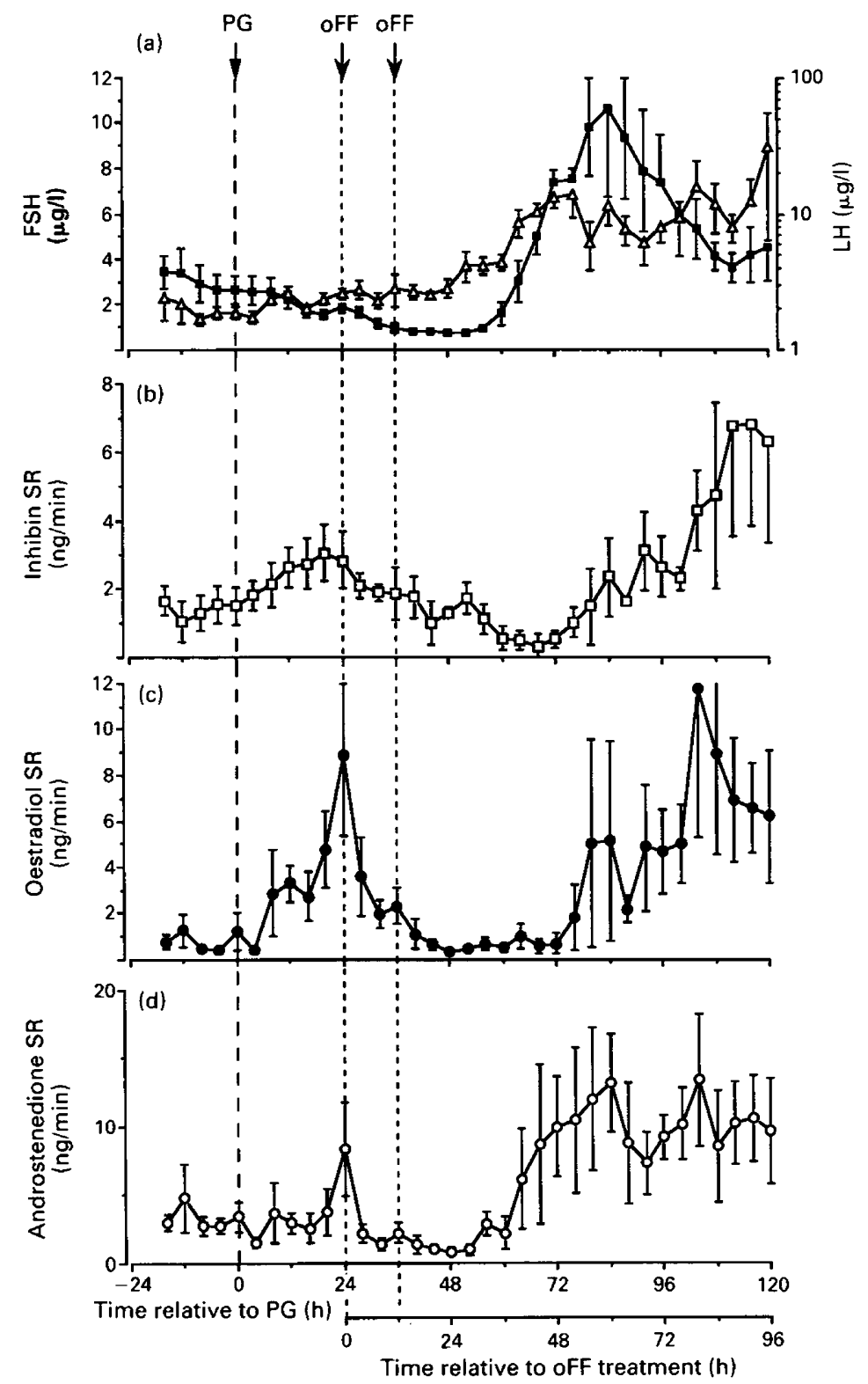

Fig. 3. Mean ( \pm s.e.m.) jugular venous concentrations of (a) luteinizing hormone $(\triangle, L H)$ and follicle-stimulating hormone ( $\mathbf{a}, \mathbf{F S H})$ and ovarian secretion rates (SR) of (b) inhibin, (c) oestradiol and (d) androstenedione in 4 ewes which received 2 injections (arrows) of steroid-free ovine follicular fluid (oFF, $3 \mathrm{ml}$ s.c.) 24 and $36 \mathrm{~h}$ after the induction of luteolysis with cloprostenol (PG, arrow) on Day 10 of the luteal phase. In calculating the ovarian secretion rate of inhibin, the concentration of inhibin in jugular venous plasma has been subtracted from the concentration of inhibin in ovarian venous plasma, therefore giving a true index of the ovarian response to the injection of oFF.

Ovarian hormone secretion rates. The effects of oFF and IFoFF on ovarian hormone secretion were similar, the rate for oestradiol, androstenedione and inhibin beginning to decline within $8 \mathrm{~h}$ of the first injection $(P<0.001 ;$ Figs $3 \& 4)$. The rate of decrease was more marked for the steroids, a 


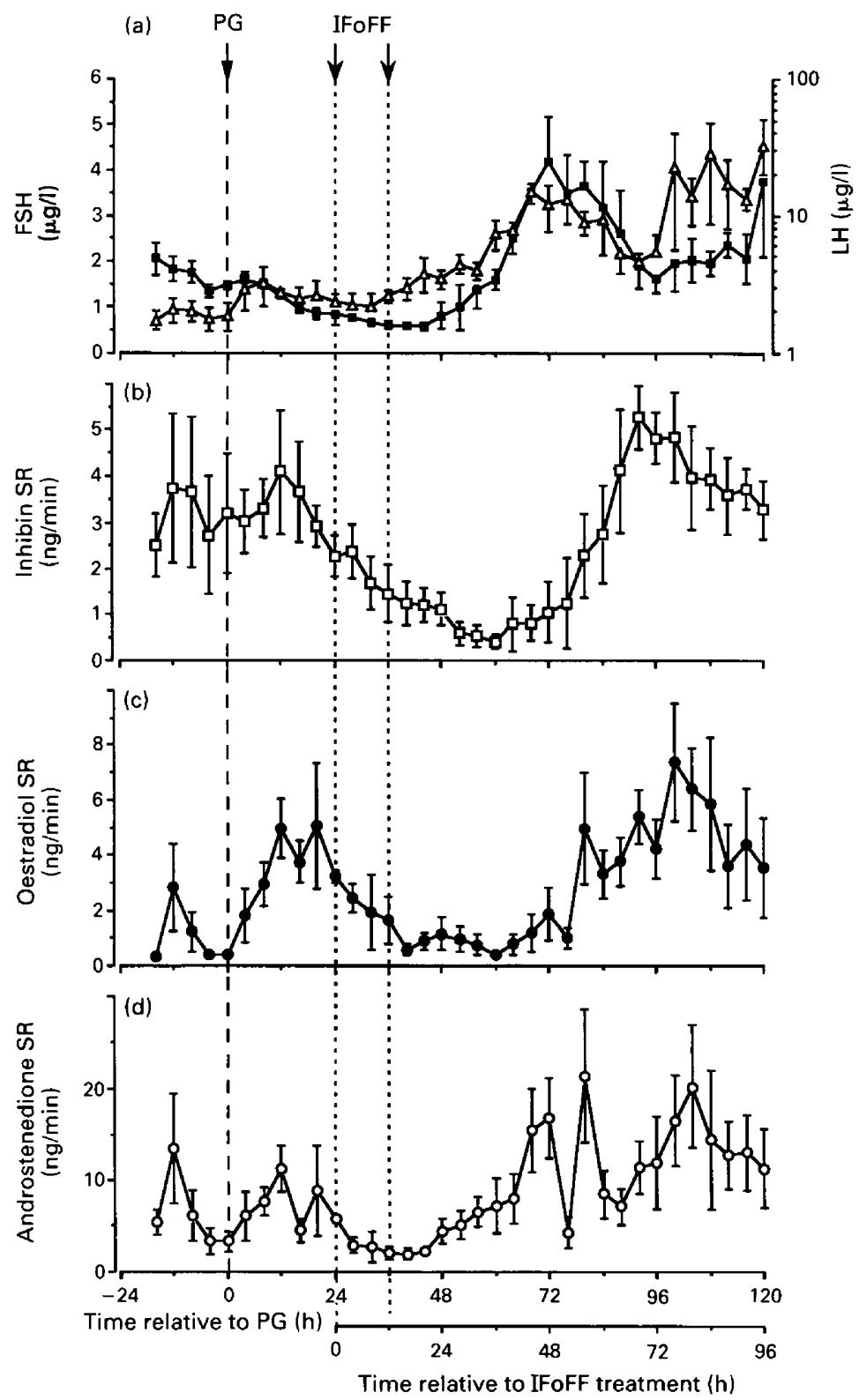

Fig. 4. Mean ( \pm s.e.m.) jugular venous concentrations of (a) luteinizing hormone $(\triangle, \mathrm{LH})$ and follicle-stimulating hormone ( $\boldsymbol{\square}, \mathrm{FSH}$ ) and ovarian secretion rates (SR) of (b) inhibin, (c) oestradiol and (d) androstenedione of 4 ewes which received 2 injections of steroid- and inhibin-free ovine follicular fluid (IFoFF, $3 \mathrm{ml} \mathrm{s.c.,} \mathrm{arrows)} 24$ and $36 \mathrm{~h}$ after the induction of luteolysis with cloprostenol (PG, arrow) on Day 10 of the luteal phase.

mean nadir of $<1 \mathrm{ng} / \mathrm{min}$ being reached within $12-24 \mathrm{~h}$ of treatment whereas inhibin secretion did not reach a nadir until 36-44 h after treatment. Re-establishment of ovarian hormone secretion also occurred at different times. Androstenedione secretion began to increase $(P<0.05)$ within $24 \mathrm{~h}$ of treatment whereas inhibin and oestradiol secretion did not begin to increase significantly $(P<0.05)$ until $48-60 \mathrm{~h}$ after treatment (Figs $3 \& 4)$. In most ewes, ovarian hormone secretion 
Table 1. Pulsatile hormone secretion (mean \pm s.e.m.) during the late follicular phase of the oestrous cycle (48-52 h after (PG)) in ewes given either steroid-free ovine follicular fluid (oFF) $(n=4)$ or steroid- and inhibin-free oFF (IFoFF; $n=$ 4) 24 and $36 \mathrm{~h}$ after PG. Data from similar untreated ewes sampled for blood at the same stage of the oestrous cycle are included for comparison $(n=11$; Baird et al., 1990a; Campbell et al., 1990b)

\begin{tabular}{llclc}
\hline Hormone & Treatment & $\begin{array}{c}\text { Pulse interval } \\
\text { (min) }\end{array}$ & $\begin{array}{c}\text { Pulse } \\
\text { amplitude }\end{array}$ & Nadir \\
\hline Luteinizing hormone & Control & $44 \cdot 3 \pm 3 \cdot 4$ & $1 \cdot 3 \pm 0 \cdot 3$ & $2 \cdot 2 \pm 0 \cdot 4$ \\
(ng/ml) & oFF & $53 \cdot 1 \pm 7 \cdot 6$ & $2 \cdot 6 \pm 0 \cdot 3^{*}$ & $2 \cdot 5 \pm 0 \cdot 3$ \\
& IFoFF & $55 \cdot 0 \pm 4 \cdot 3$ & $3 \cdot 5 \pm 0 \cdot 9^{* *}$ & $2 \cdot 8 \pm 0 \cdot 3$ \\
Oestradiol (ng/min) & Control & $46 \cdot 7 \pm 3 \cdot 8$ & $9 \cdot 2 \pm 2 \cdot 3$ & $6 \cdot 6 \pm 1 \cdot 7$ \\
& oFF & $200 \cdot 0 \pm 40 \cdot 0^{*}$ & $1 \cdot 5 \pm 0 \cdot 3^{* *}$ & $0 \cdot 2 \pm 0 \cdot 1^{* *}$ \\
& IFoFF & $150 \cdot 0 \pm 52 \cdot 0^{*}$ & $1 \cdot 3 \pm 0 \cdot 6^{* *}$ & $0 \cdot 4 \pm 0 \cdot 3^{* *}$ \\
Androstenedione & Control & $44 \cdot 6 \pm 4 \cdot 5$ & $6 \cdot 3 \pm 0 \cdot 9$ & $4 \cdot 4 \pm 0 \cdot 8$ \\
(ng/min) & oFF & $42 \cdot 1 \pm 4 \cdot 5$ & $1 \cdot 1 \pm 1 \cdot 0^{* *}$ & $0 \cdot 8 \pm 0 \cdot 5^{*}$ \\
& IFoFF & $48 \cdot 0 \pm 7 \cdot 5$ & $4 \cdot 3 \pm 1 \cdot 8^{\dagger}$ & $1.9 \pm 0 \cdot 7^{*}$ \\
Inhibin (ng/min) & Control & $43 \cdot 2 \pm 2 \cdot 8$ & $2 \cdot 1 \pm 0 \cdot 3$ & $2 \cdot 3 \pm 0 \cdot 5$ \\
& oFF & $141 \cdot 0 \pm 47 \cdot 0^{*}$ & $1 \cdot 2 \pm 0 \cdot 3^{*}$ & $0 \cdot 6 \pm 0 \cdot 3^{*}$ \\
& IFoFF & $198 \cdot 0 \pm 43 \cdot 0^{*}$ & $1 \cdot 3 \pm 0 \cdot 3^{*}$ & $0 \cdot 2 \pm 0 \cdot 1^{*}$ \\
\hline
\end{tabular}

${ }^{*} P<0.05 ;{ }^{* *} P<0.01$; significantly different from normal untreated animals.

†Significantly different from ewes treated with oFF $(P<0.05)$.

increased until $72 \mathrm{~h}$ after treatment, after which mean secretion rates tended to reach a plateau, although there was a great deal of variation in the pattern of secretion in individual animals due to the occurrence of preovulatory LH surges at different times.

LH pulse interval and nadir were normal in ewes treated with oFF or IFoFF. LH pulse amplitude was higher $(P<0.05)$ than in normal untreated ewes in both groups. However, the treatment had different effects on the pattern of pulsatile secretion for individual hormones. By $24-28 \mathrm{~h}$ after treatment with oFF or IFoFF, the pattern of androstenedione secretion was normal, each pulse of LH being followed by a pulsatile release of androstenedione (Fig. 5), although the androstenedione pulse amplitude and nadir were depressed compared with untreated ewes during the late follicular phase (Table 1). Despite frequent LH pulses, oestradiol secretion in both groups of treated ewes was not responsive to $\mathrm{LH}$ and, although statistically significant pulses were observed, they were of low amplitude and nadir, with the result that oestradiol pulse interval, amplitude and nadir were all depressed $(P<0.05)$ by oFF and IFoFF. Pulsatile inhibin secretion was similarly depressed $(P<0.05)$ in ewes treated with oFF or IFoFF (Table 1; Fig. 5).

\section{Patterns of follicular growth and hormone secretion}

Before treatment, both groups of ewes had ovaries containing, on average, 2-3 large (diameter $>3.5 \mathrm{~mm}$ ) ovarian follicles (Fig. 6). Injection of oFF or IFoFF caused a marked decline $(P<0.01)$ in the number of large follicles within $48 \mathrm{~h}$ of treatment and, concomitant with the rebound release of FSH, an increase $(P<0.01)$ in the number of small follicles/ovary. By $96 \mathrm{~h}$ after treatment, the number of large follicles per ewe had increased $(P<0.05)$ to pretreatment levels, concomitant with a decline $(P<0.05)$ in the number of small follicles.

In all individual animals, changes in gonadotrophin concentrations, ovarian hormone secretion rates and number of ovarian follicles were temporally related (Figs $7 \& 8$ ). Follicles in the ovary at the time of injection of oFF or IFoFF slowly decreased in diameter as the ovarian secretion of androstenedione, inhibin and oestradiol dropped. As ovarian secretion fell, the concentrations of LH and FSH in jugular venous plasma increased and a number of small follicles were detected in the ovary. As these follicles grew, the ovarian secretion of first androstenedione and then inhibin and oestradiol was re-established and the concentrations of FSH and LH in venous plasma 

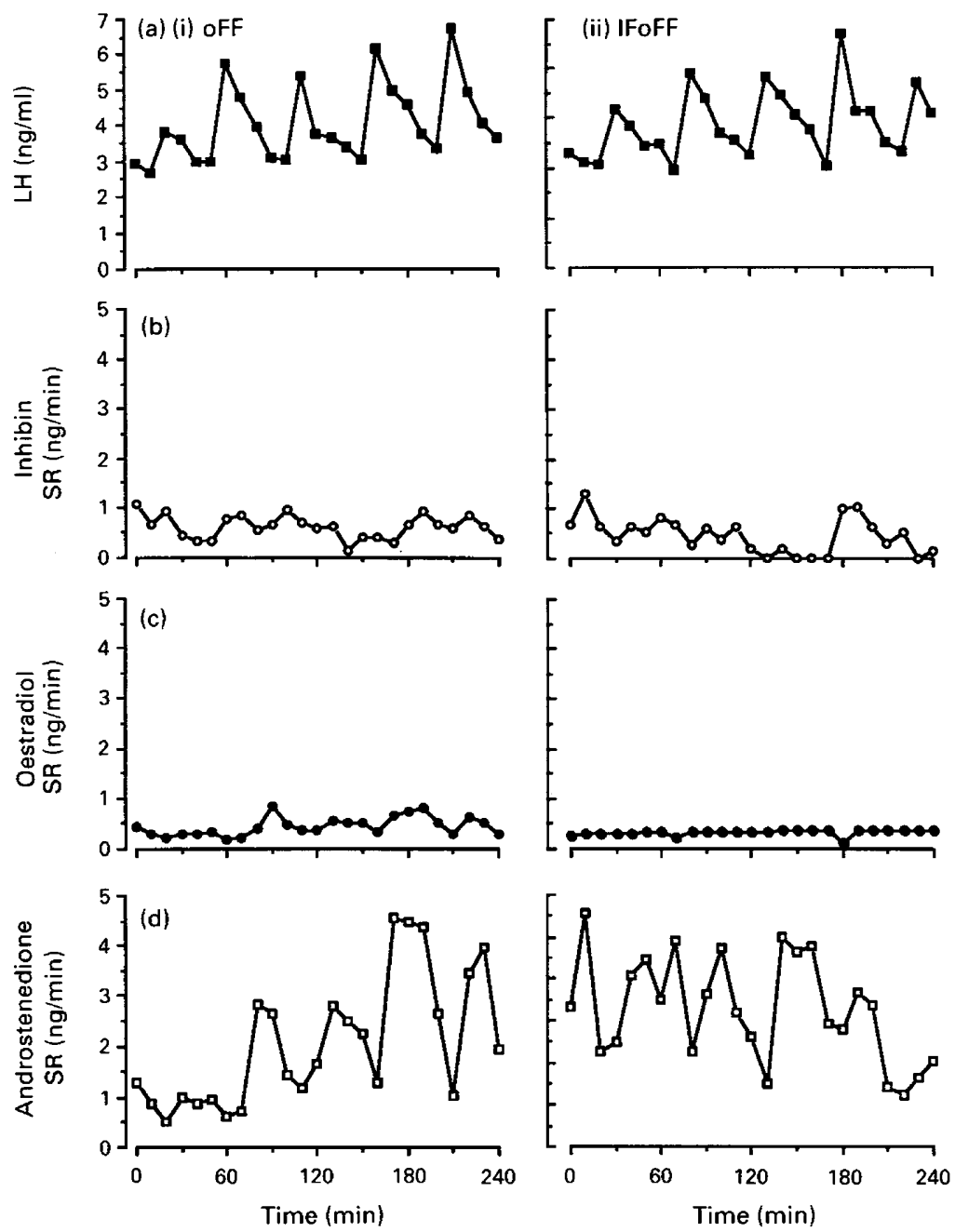

Fig. 5. Profiles of secretion rate(SR) of (a) luteinizing hormone(LH), (b) inhibin, (c) oestradiol and (d) androstenedione during the late follicular phase of the oestrous cycle (48-52 $\mathrm{h}$ after injection with cloprostenol (PG)) in a ewe which received either (i) steroid-free ovine follicular fluid (ewe $2 \mathrm{G3}$; oFF, $3 \mathrm{ml} \mathrm{s.c.)} \mathrm{or} \mathrm{(ii)} \mathrm{steroid-} \mathrm{and} \mathrm{inhibin-free} \mathrm{ovine} \mathrm{follicular} \mathrm{fluid} \mathrm{(ewe} \mathrm{2G20;} \mathrm{IFoFF,} 3 \mathrm{ml}$ s.c.) 24 and $36 \mathrm{~h}$ after the induction of luteolysis with PG on Day 10 of the luteal phase.

declined. In the ewe treated with oFF (Fig. 7), the preovulatory LH surge occurred at the end of the experimental period ( $120 \mathrm{~h}$ after $\mathrm{PG}$ ) and was preceded by the characteristic increase in oestradiol secretion. The ewe treated with IFoFF (Fig. 8) had a preovulatory LH surge, accompanied by a simultaneous FSH peak, within $92 \mathrm{~h}$ of PG and the surge was followed by the characteristic marked decline in the secretion of oestradiol and androstenedione (Baird \& McNeilly, 1981; Campbell et al., 1990a).

\section{Discussion}

The results of this experiment confirm our previous observation (Baird et al., 1990a) that injection of steroid-free oFF during the late follicular phase results in a profound decrease in the concentration of FSH in jugular venous plasma, followed by a rapid decline in the ovarian secretion of 


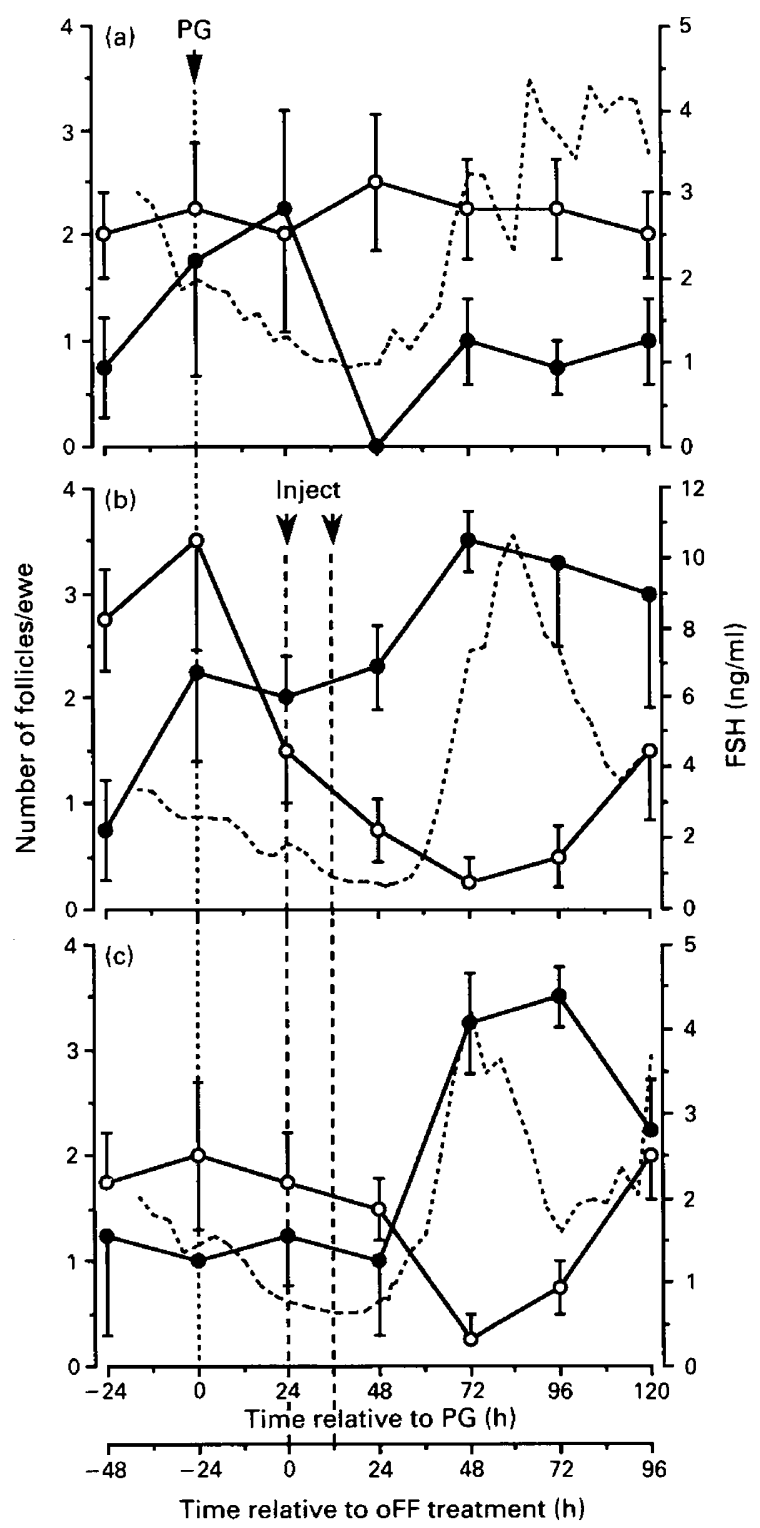

Fig. 6. Mean ( \pm s.e.m.) numbers of small $(O$, diameter $2-3.5 \mathrm{~mm})$ or large $(O$, diameter $\geqslant 3.5 \mathrm{~mm}$ ) follicles as determined by daily ultrasound scanning in (a) normal ewes treated with cloprostenol (PG, arrow) on Day 10 of the luteal phase to induce luteolysis $(n=4)$, (b) ewes which received 2 injections of steroid-free ovine follicular fluid 24 and $36 \mathrm{~h}(\mathrm{oFF}, 3 \mathrm{ml}$ s.c., arrows) after the induction of luteolysis with PG on Day 10 of the luteal phase $(n=4)$ or (c) ewes which received 2 injections of steroid- and inhibin-free ovine follicular fluid 24 and $36 \mathrm{~h}$ (IFoFF, $3 \mathrm{ml}$ s.c., arrows) after the induction of luteolysis with PG on Day 10 of the luteal phase $(n=4)$. Mean concentration of follicle-stimulating hormone (FSH) in jugular venous plasma (-- ) is presented for each group to emphasize the relationships between FSH and changes in the follicle population.

oestradiol, androgens and inhibin that is followed by a marked increase in the concentration of FSH and LH and a delay in ovulation. Further, the use of real-time ultrasound has shown that the depression in ovarian hormone secretion, which results from the injection of oFF, was caused by 


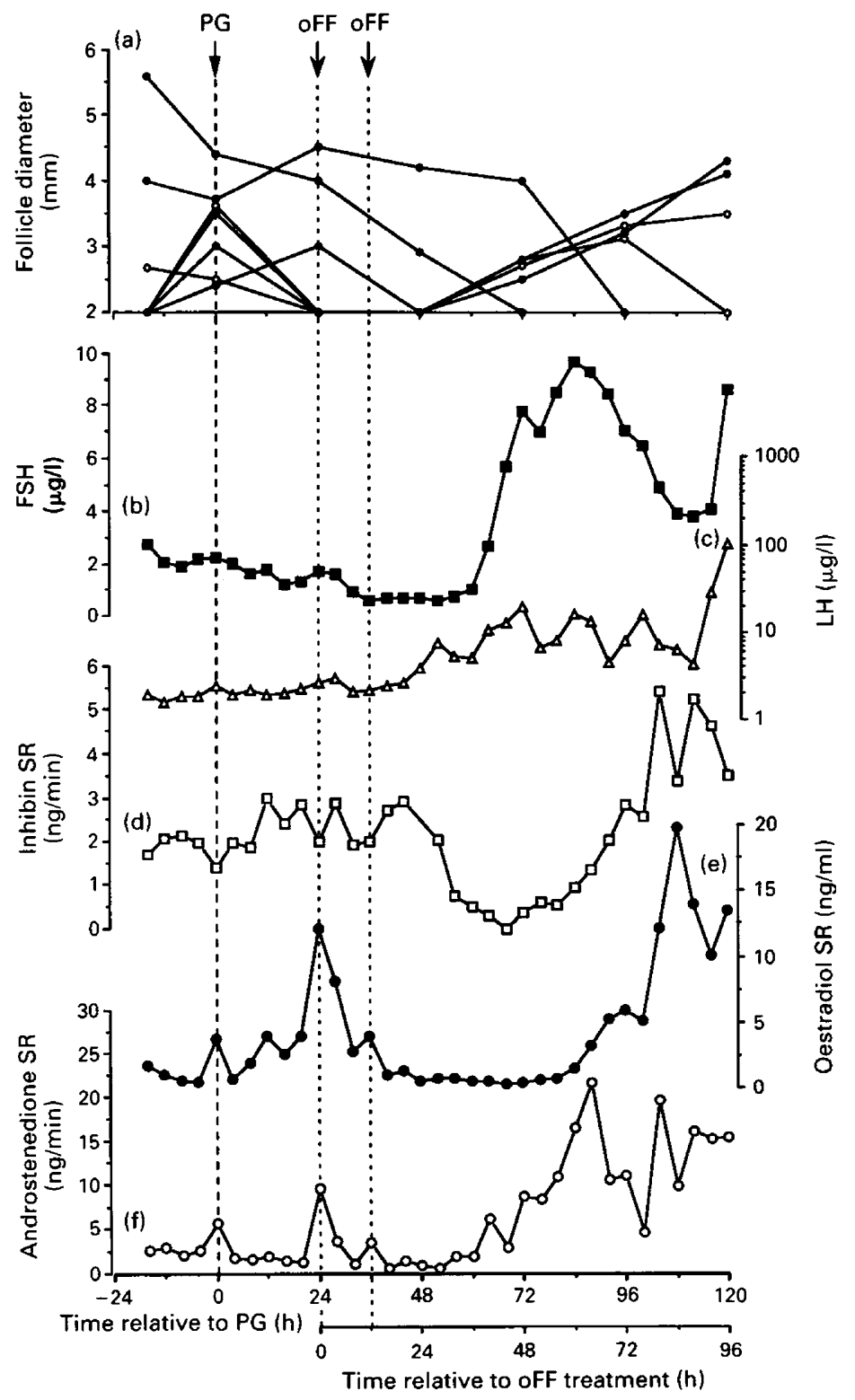

Fig. 7. (a) Diameter of all individual follicles detected by ultrasound scanning and jugular venous concentrations of (b) follicle-stimulating hormone ( $\square$, FSH) and (c) luteinizing hormone $(\triangle, \mathbf{L H})$ and ovarian secretion rates $(\mathrm{SR})$ of $(\mathrm{d})$ inhibin $(\square)$, (e) oestradiol $(\mathrm{O})$ and (f) androstenedione $(O)$ in the ovary of a single ewe (2G8) which received 2 injections of steroidfree ovine follicular fluid (oFF, $3 \mathrm{ml}$ s.c., arrows) 24 and $36 \mathrm{~h}$ after the induction of luteolysis with cloprostenol (PG, arrow) on Day 10 of the luteal phase. In calculating the ovarian secretion rate of inhibin, the concentration of inhibin in jugular venous plasma has been subtracted from the concentration in ovarian venous plasma, therefore giving a true index of the ovarian response to the injection of oFF. 


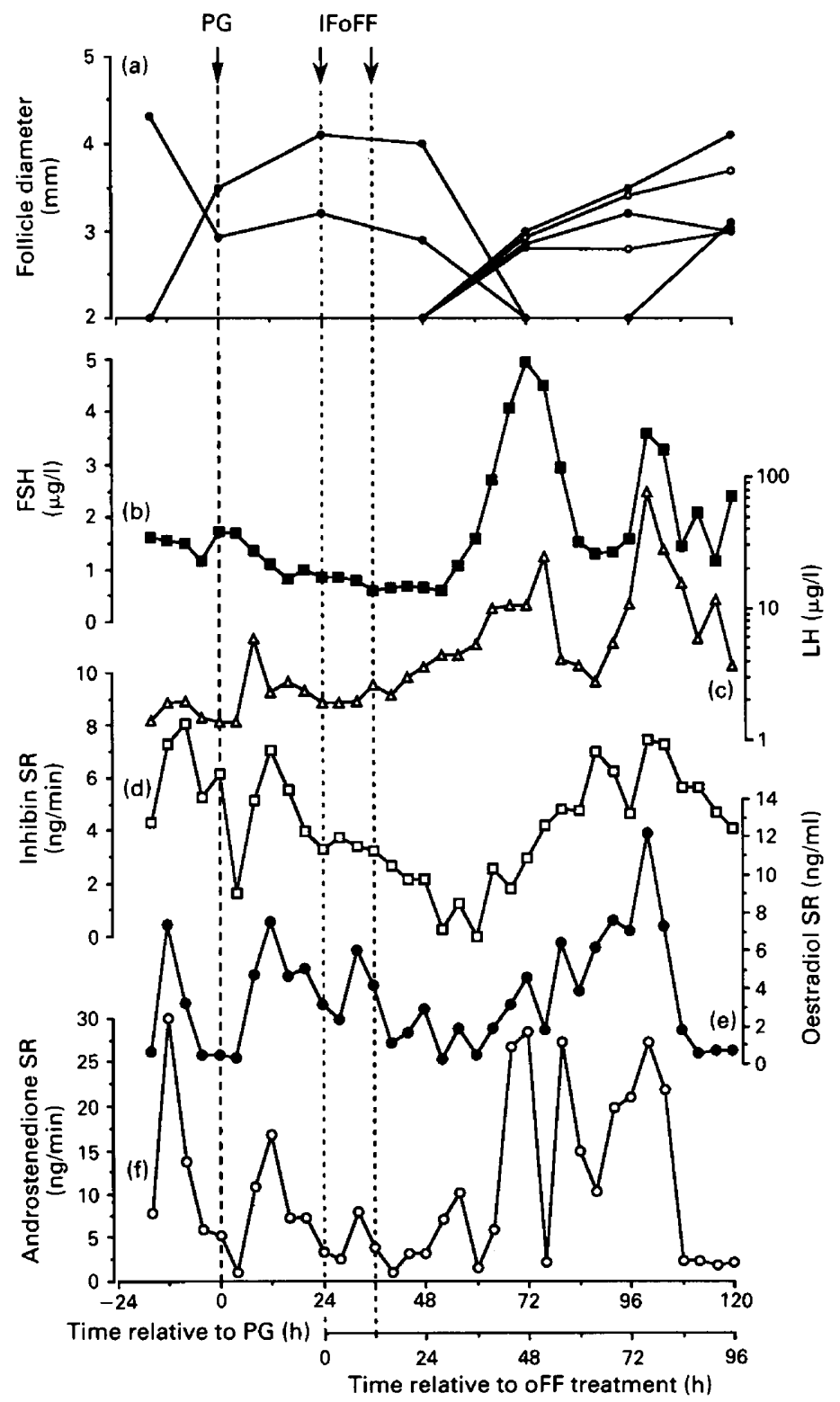

Fig. 8. (a) Diameter of all individual follicles detected by ultrasound scanning and jugular venous concentrations of (b) follicle-stimulating hormone ( $\boldsymbol{\square}, \mathrm{FSH})$ and (c) luteinizing hormone $(\triangle, L H)$ and ovarian secretion rates (SR) of (d) inhibin $(\square)$, (e) oestradiol $(O)$ and (f) androstenedione $(O)$ in the ovary of a single ewe $(2 \mathrm{Gl})$ which received 2 injections of steroidand inhibin-free ovine follicular fluid (IFoFF, $3 \mathrm{ml}$ s.c., arrows) 24 and $36 \mathrm{~h}$ after the induction of luteolysis with cloprostenol (PG, arrow) on Day 10 of the luteal phase.

the induction of atresia in large ovarian follicles and that the rebound release of FSH induced the growth of small follicles (Picton 1989; Picton et al., 1990; McNeilly et al., 1990). These follicles initially secreted mainly androstenedione (Carson et al., 1981; McNatty et al., 1981), but, as they grow under the influence of FSH (Tsonis et al., 1988; Picton, 1989; McNeilly et al., 1990; Picton et al., 1990), they secrete more inhibin and oestradiol (Tsonis et al., 1983; Campbell et al., 1991) 
suppressing the secretion of FSH and LH by the pituitary (Karsch et al., 1984; Martin, 1984; Martin et al., 1988; Baird et al., 1990b), until sufficient oestradiol is secreted to induce the preovulatory LH surge (Baird \& McNeilly, 1981). Although the results of the ovarian scanning showed clearly that oFF inhibited the growth of large follicles, its effect on small follicles was less clear, as these follicles are harder to detect and measure accurately than large follicles. Following treatment with oFF or IFoFF, however, the secretion rate of androstenedione did not fall below $1 \mathrm{ng} / \mathrm{min}$ (range $1-4 \mathrm{ng} / \mathrm{min}$ ), which is similar to the secretory capacity of ovaries containing only small follicles (Campbell et al., 1991). This indirect evidence therefore suggests that the oFF had little effect on the existing small follicles, a conclusion supported by studies where bovine follicular fluid has been administered to sheep during anoestrus (McNatty et al., 1985) and the luteal phase of the oestrous cycle (Wallace et al., 1985; A. S. McNeilly, unpublished observations).

Injection of steroid-free oFF, the inhibin content of which had been reduced by $90 \%$, had no significant effect on the concentration of either inhibin or FSH in jugular venous plasma, yet resulted in similar suppression of ovarian follicle growth and hormone secretion to that obtained following treatment with oFF containing inhibin. This observation indicates that the inhibitory action of oFF on follicular growth is not mediated by inhibin, acting either indirectly through the suppression of FSH, or directly on the ovary (Ying et al., 1986). These results suggest that follicular fluid contains other factors that are capable of directly inhibiting the growth of large ovarian follicles. Although not statistically significant, there was a slight decline in blood FSH concentrations after injection of IFoFF, which can be attributed to the residual inhibin remaining in the IFoFF in combination with a continuation of the normal fall in FSH that occurs during the follicular phase (Baird et al., 1981; Campbell et al., 1990a). The possibility, therefore, exists that this slight decline in FSH was sufficient to inhibit follicular growth. However, the magnitude of this decline was extremely variable (see, for example, ewe 2 G18 in Fig. 7) whereas the inhibitory effects of the IFoFF were remarkably consistent. The fall and subsequent rise in the concentration of inhibin in jugular venous plasma from ewes given IFoFF reflects the inhibition and re-establishment of ovarian inhibin secretion, which was presumably masked in ewes given oFF. The later rise in the concentration of LH in ewes treated with oFF than in those treated with IFoFF suggests that large doses of inhibin may depress LH secretion by the pituitary. The increase in LH pulse amplitude observed in both treatment groups can be attributed to a loss of oestradiol negative feedback in the absence of progesterone (Karsch et al., 1984; Martin, 1984).

The intraovarian theory for the maintenance of the selected follicle states that the preovulatory follicle maintains its dominance through the secretion of follicle growth inhibitor(s) which act within the ovaries (Driancourt, 1987; Ireland, 1987). The presence of follicular inhibitory activity in IFoFF provides experimental evidence to support this hypothesis. The identity of the inhibitory activity in oFF is unclear, although its existence is also supported by the observations of L. P. Cahill that oFF can inhibit the action of PMSG to stimulate follicular development in hypophysectomized (Cahill, 1984) or normal (Cahill et al., 1985) ewes. Similar observations have been made in cattle given inhibin-free bFF (Law et al., 1990). Follicle regulatory protein, which has been isolated from follicular fluid (diZerega et al., 1982; Ono et al., 1986), has been shown to inhibit granulosa cell aromatase activity (see Ono et al., 1986). It does not, however, affect thecal androgen production in vitro (Tonetta, 1987; Tonetta et al., 1988), which is in contrast to the in-vivo effects of oFF (Figs 2 \& 3; Baird et al., 1990a). Similarly, while EGF (Scaramuzzi et al., 1988) and transforming growth factor $\alpha(\mathrm{TGF} \alpha)$ (Murray et al., 1990) inhibit ovarian oestradiol secretion in vivo, neither EGF (Scaramuzzi et al., 1988) nor TGF $\alpha$ (Murray et al., 1990) affect ovarian androstenedione secretion. In the latter studies, however, blood samples were not taken until $24 \mathrm{~h}$ after the end of treatment and androstenedione secretion may have become re-established in that time, as was observed in the present experiment. Another possible inhibitor of ovarian function in follicular fluid is insulin-like, growth-factor-binding protein (IGF-BP: Shimasaki et al., 1990) which inhibits FSH-induced oestradiol and progesterone production in cultured rat granulosa cells (Ui et al., 1989). No data are available on the in-vivo effect of IGF-BP on ovarian steroid secretion. As the 
attainment of oestrogenicity is a key event in follicular development (Baird, 1983), inhibition of aromatase alone may result in follicular atresia, although the acuteness of the effect of oFF on androgen secretion would seem to make this mechanism unlikely. The identity and mode of action of the follicular inhibitory activity in oFF therefore remains to be determined. The observation that oFF, in similar doses to those used in the present experiment, is unable to prevent FSH from stimulating follicle development in ewes treated with a potent GnRH-agonist (A. S. McNeilly \& B. K. Campbell, unpublished observations) suggests that the inhibitor ultimately modulates an FSH-dependent process and that the action of the inhibitor can be overcome by FSH.

We conclude that oFF contains a factor that acts directly on the ovary to induce atresia of large preovulatory follicles and results in immediate suppression of ovarian inhibin, oestradiol and androstenedione secretion. The lack of feedback of ovarian hormones results in a rebound release of FSH, which stimulates the growth of ovarian follicles and the eventual re-establishment of ovarian hormone secretion and normal cyclicity.

We thank Miss N. Anderson, Miss L. Harkness and Mr I. Miller for expert technical assistance, Mr T. McFetters and Mr E. Pinner for artwork, Professor L. E. Reichert, Jr, Union University, Albany, NY, USA, Dr J. Rivier, Salk Institute, La Jolla, CA, USA and the NIADDK and the National Hormone and Pituitary Program, University of Maryland School of Medicine, USA and Dr B. Cook, Department of Chemistry Pathology, Royal Infirmary, Glasgow for some of the hormones used in the radioimmunoassays. This work was supported by MRC Programme Grant G426375.

\section{References}

Al-Obaidi, S.A.R., Bindon, B.M., Findlay, J.K., Hillard, M.A. \& O'Shea, T. (1987) Plasma follicle stimulating hormone in Merino ewes immunized with an inhibinenriched fraction from bovine follicular fluid. Anim. Reprod. Sci. 14, 39-51.

Baird, D.T. (1983) Factors regulating the growth of the preovulatory follicle in the sheep and human. In The Control of Follicle Development and Ovulation, pp. 343-352. Eds G. E. Lamming, D. T. Baird \& B. J. Weir. Journals of Reproduction and Fertility Ltd, Cambridge.

Baird, D.T. \& McNeilly, A.S. (1981) Gonadotrophic control of follicular development and function during the oestrous cycle of the ewe. J. Reprod. Fert., Suppl. 30, 119-133.

Baird, D.T., Swanston, I.A. \& McNeilly, A.S. (1981) Relationship between LH, FSH, and prolactin concentration and the secretion of androgens and estrogens by the preovulatory follicle in the ewe. Biol. Reprod. 24, 1013-1025.

Baird, D.T., Campbell, B.K. \& McNeilly, A.S. (1990a) Ovine follicular fluid suppresses the ovarian secretion of androgens, oestradiol and inhibin. J. Endocr. 127, 23-32.

Baird, D.T., Campbell, B.K., Mann, G.E. \& McNeilly, A.S. (1990b) Inhibin and oestradiol in the control of FSH secretion in the sheep. J. Reprod. Fert., Suppl. 43, 125-138.

Cahill, L.P. (1984) Folliculogenesis and ovulation rate in sheep. In Reproduction in Sheep, pp. 92-98. Eds D. R. Lindsay \& D. T. Pearce. Australian Wool Corporation, Canberra.

Cahill, L.P., Driancourt, M.A., Chamley, W.A. \& Findlay, J.K. (1985) Role of intrafollicular regulators and FSH in growth and development of large antral follicles in sheep. J. Reprod. Fert. 75, 599-607.

Campbell, B.K., McNeilly, A.S. \& Baird, D.T. (1989) Episodic ovarian inhibin secretion is not due to $\mathrm{LH}$ pulses in anoestrous ewes. J. Endocr. 123, 173-179.

Campbell, B.K., Mann, G.E., McNeilly, A.S. \& Baird, D.T. (1990a) The pattern of ovarian inhibin, estradiol and androstenedione secretion during the estrous cycle of the ewe. Endocrinology 127, 227-235.

Campbell, B.K., Mann, G.E., McNeilly, A.S. \& Baird, D.T. (1990b) Pulsatile secretion of inhibin, oestradiol and androstenedione by the ovary of the sheep during the oestrous cycle. $J$. Endocr. 126, 385393.

Campbell, B.K., McNeilly, A.S., Mann, G.E. \& Baird, D.T. (1991) The effect of stage of estrous cycle and follicular maturation on ovarian inhibin production in sheep. Biol. Reprod. 44, 483-490.

Carson, R.S., Findlay, J.K., Clarke, I.J. \& Burger, H.G. (1981) Estradiol, testosterone, and androstenedione in ovine follicular fluid during growth and atresia of ovarian follicles. Biol. Reprod. 24, 105-113.

Collett, R.A., Land, R.B. \& Baird, D.T. (1973) The pattern of progesterone secretion by the autotransplanted ovary of the ewe in response to ovine luteinizing hormone. J. Endocr. 56, 403-411.

Cummins, L.J., O'Shea, T., Al-Obaidi, S.A.R., Bindon, B.M. \& Findlay, J.K. (1986) Increase in ovulation rate after immunization of Merino ewes with a fraction of bovine follicular fluid containing inhibin activity. $J$. Reprod. Fert. 77, 365-372.

Driancourt, M.A. (1987) Follicular dynamics and intraovarian control of follicular development in the ewe. In Follicular Growth and Ovulation Rate in 
Farm Animals, pp. 87-105. Eds J. F. Roche \& D. O'Callaghan, Martinus Nijhoff Publishers, Dordrecht.

diZerega, G.S., Goebelsmann, U. \& Nakamura, R.M. (1982) Identification of protein(s) secreted by the preovulatory ovary which suppresses the follicle response to gonadotrophins. J. Clin. Endocrinol. Metab. 54, 1091-1096.

Goding, J.R., McCracken, J.A. \& Baird, D.T. (1967) The study of ovarian function in the ewe by means of a vascular autotransplantation technique. $J$. Endocr. 39, 37-52.

Henderson, K.M., Franchimont, P., Lecomte-Yerna, M.J., Hudson, N. \& Ball, K. (1984) Increase in ovulation rate after active immunization of sheep with inhibin partially purified from bovine follicular fluid. J. Endocr. 102, 305-309.

Henderson, K.M., Prisk, M.D., Hudson, N., Ball, K., McNatty, K.P., Lun, S., Heath, D., Kieboom, L.E. \& McDiarmid, J. (1986) Use of bovine follicular fluid to increase ovulation rate or prevent ovulation in sheep. J. Reprod. Fert. 76, 623-635.

Henderson, K.M., Savage, L.C., Ellen, R.L., Ball, K. \& McNatty, K.P. (1988) Consequences of increasing or decreasing plasma FSH concentrations during the preovulatory period in Romney ewes. J. Reprod. Fert. 84, 187-196.

Hsu, C.-J., Holmes, S.D. \& Hammond, J.M. (1987) Ovarian epidermal growth factor-like activity. Concentrations in porcine follicular fluid during follicular enlargement. Biochem. Biophys. Res. Comm. 147, 242-247.

Hsueh, A.J.W., Adashi, E.Y., Jones, P.B.C. \& Welsh, T.H. (1984) Hormonal regulation of the differentiation of cultured ovarian granulosa cells. Endocr. Rev. 5, 76-127.

Ireland, J.J. (1987) Control of follicular growth and development. J. Reprod. Fert., Suppl. 34, 39-54.

Karsch, F.J., Bittman, E.L., Foster, D.L., Goodman, R.L., Legan, S.J. \& Robinson, J.E. (1984) Neuroendocrine basis of seasonal reproduction. Rec. Progr. Horm. Res. 40, 185-232.

Law, A.S., Logue, D.N., O'Shea, T. \& Webb, R. (1990) Evidence for a novel factor in steroid-free bovine follicular fluid (bFF) which acts to directly suppress follicular development. J. Reprod. Fert., Abstr. Ser. 5, p. 4, abstr. S3.

Leversha, L.J., Robertson, D.M., deVos, F.L., Morgan, F.J., Hearn, M.T.W., Wettenhall, R.E.H., Findlay, J.K., Burger, H.G. \& de Kretser, D.M. (1987) Isolation of inhibin from ovine follicular fluid. $J$. Endocr. 113, 213-221.

Mann, G.E., Campbell, B.K., McNeilly, A.S. \& Baird, D.T. (1989) Passively immunizing ewes against inhibin during the luteal phase of the oestrous cycle raises the plasma concentration of FSH. J. Endocr. 123, 383-391.

Mann, G.E., Campbell, B.K., McNeilly, A.S. \& Baird, D.T. (1990) The effect on plasma FSH of passively immunizing ewes against inhibin and oestradiol during the follicular phase of the oestrous cycle. $J$. Endocr. 125, 417-424.

Martin, G.B. (1984) Factors affecting the secretion of luteinizing hormone in the ewe. Biol. Rev. 59, 1-87.
Martin, G.B., Price, C.A., Thiery, J.-C. \& Webb, R. (1988) Interactions between inhibin, oestradiol and progesterone in the control of gonadotrophin secretion in the ewe. J. Reprod. Fert. 82, 319-328.

MeNatty, K.P., Gibb, M., Dobson, C., Thurley, D.C. \& Findlay, J.K. (1981) Changes in the concentration of gonadotrophic and steroidal hormones in the antral fluid of ovarian follicles throughout the oestrous cycle of the sheep. Aust. J. Biol. Sci. 24, 67-80.

McNatty, K.P., Gibb, M., Dobson, C., Ball, K., Coster, J., Heath, D.\& Thurley, D.C. (1982) Preovulatory follicular development in sheep treated with PMSG and/or prostaglandin. J. Reprod. Fert. 65, 111-123.

McNatty, K.P., Hudson, N., Gibb, M., Ball, K., Henderson, K.M., Heath, D.A., Lun, S. \& Kieboom, L.E. (1985) FSH influences follicle viability, oestradiol biosynthesis and ovulation rate in Romney ewes. $J$. Reprod. Fert. 75, 121-131.

McNeilly, A.S. (1984) Changes in FSH and the pulsatile secretion of LH during the delay in oestrus induced by treatment of ewes with bovine follicular fluid. $J$. Reprod. Fert. 72, 165-172.

McNeilly, A.S. (1985) Effect of changes in FSH induced by bovine follicular fluid and FSH infusion in the preovulatory phase on subsequent ovulation rate and corpus luteum function in the ewe. J. Reprod. Fert. 74, 661-668.

McNeilly, A.S. \& Fraser, H.M. (1987) Effect of gonadotropin-releasing hormone agonist induced suppression of $\mathrm{LH}$ and $\mathrm{FSH}$ on follicle growth and corpus luteum function in the ewe. J. Endocr. 115, 273-282.

McNeilly, A.S., Jonassen, J.A., Fraser, H.M. (1986) Suppression of follicular development after chronic LHRH immunoneutralization in the ewe. J. Reprod. Fert. 76, 481-490.

McNeilly, A.S., Swanston, I.A., Crow, W., Tsonis, C.G. \& Baird, D.T. (1989) Changes in plasma concentrations of inhibin throughout the normal sheep oestrous cycle and after infusion of FSH. $J$. Endocr. 120, 295-305.

McNeilly, A.S., Picton, H.M., Campbell, B.K. \& Baird, D.T. (1990) Gonadotrophic control of follicle growth in the ewe. J. Reprod. Fert., Suppl. 43, 177-186.

Murray, J.F., Downing, J.A., Evans, G., Findlay, J.K. \& Scaramuzzi, R.J. (1989) Epidermal growth factor (EGF) inhibits inhibin secretion in the follicular phase of the oestrous cycle. Proc. Aust. Soc. Reprod. Biol. 21, 136, abstr.

Murray, J.F., Downing, J. A., Evans, G. \& Scaramuzzi, R.J. (1990) TGF $\alpha$ acts directly on the ovarian follicle. Proc. Aust. Soc. Reprod. Biol. 22, 136 (Abstr.)

Ono, T., Campeau, J.D., Holmberg, E.A., Nakamura, R.M., Ujita, E.L., Tonetta, S.A., DeVina, R., Ugalde, M. \& diZerega, G.S. (1986) Biochemical and physiologic characterization of follicle regulatory protein: a paracrine regulator of folliculogenesis. Amer. J. Obstetr. Gynecol. 154, 709-716.

Picton, H.M. (1989) The gonadotrophic control of ovarian follicle growth in the ewe. Ph.D. thesis, University of Edinburgh.

Picton, H.M., Tsonis, C.G. \& McNeilly, A.S. (1990) FSH causes a time-dependent stimulation of preovulatory follicle growth in the absence of pulsatile $\mathrm{LH}$ secretion in GnRH agonist treated ewes. J. Endocr. 126, 297-307. 
Radford, H.M., Panaretto, B.A., Avenell, J.A. \& Turnbull, K.E. (1987) Effect of mouse epidermal growth factor on plasma concentrations of $\mathrm{FSH}, \mathrm{LH}$, and progesterone and on oestrus, ovulation, and ovulation rate in Merino ewes. J. Reprod. Fert. 80, 383-393.

Scaramuzzi, R.J., Murray, J.F., Campbell, B.K., Downing, J.A., Evans, G. \& Panaretto, B.A. (1988) Epidermal growth factor (EGF) acts directly on the ovary in the ewe. J. Reprod. Fert., Abstr. Ser. 1, p. 31, abstr. 52.

Shimasaki, S., Shimonaka, M., Ui, M., Inouye, S., Shibata, F. \& Ling, N. (1990) Structural characterization of a follicle-stimulating hormone action inhibitor in porcine ovarian follicular fluid: its identification as the insulin-like growth factor-binding protein. J. Biol. Chem. 265, 2198-2202.

Skinner, M.K. \& Coffey, R.J., Jr (1988) Regulation of ovarian cell growth through the local production of transforming growth factor-a by theca cells. Endocrinology 123, 2632-2638.

Skinner, M.K., Keski-Oja, J., Osteen, K.G. \& Moses, H.L. (1987) Ovarian thecal cells produce transforming growth factor-beta which can regulate granulosa cell growth. Endocrinology 121, 786-792.

Tonetta, S.A. (1987) Paracrine control of $3 \beta$-hydroxysteroid dehydrogenase, 17,20-lyase and aromatase enzyme systems in porcine thecal cells. $A d v$. exp. Med. Biol. 219, 665-670.

Tonetta, S.A. \& diZerega, G.S. (1989) Intragonadal regulation of follicular maturation. Endocr. Rev. 10, 205-229.

Tonetta, S.A., DeVinna, R.S. \& diZerega, G.S. (1988) Effects of follicle regulatory protein on thecal aromatase and $3 \beta$-hydroxysteroid dehydrogenase activity in medium- and large-sized pig follicles. J. Reprod. Fert. 82, 163-171.

Tsonis, C.G., Quigg, H., Trounson, A.O. \& Findlay, J.K. (1983) The relationship between inhibin activity in follicular fluid and atresia in individual ovine follicles. In Factors Regulating Ovarian Function, pp. 163-167. Eds G. S. Greenwald \& P. F. Terranova. Raven Press, New York.
Tsonis, C.G., Cahill, L.P., Carson, R.S. \& Findlay, J.K. (1984) Identification at the onset of luteolysis of follicles capable of ovulation in the ewe. $J$. Reprod. Fert. 70, 609614.

Tsonis, C.G., McNeilly, A.S. \& Baird, D.T. (1986) Measurement of exogenous and endogenous inhibin in sheep serum using a new and extremely sensitive bioassay for inhibin based on inhibition of ovine pituitary FSH secretion in vitro. J. Endocr. 110, 341-352.

Tsonis, C.G., MeNeilly, A.S. \& Baird, D.T. (1988) Inhibin secretion by the sheep ovary during the luteal phase of the oestrous cycle and following stimulation with FSH. J. Endocr. 117, 283-291.

Ui, M., Shimonaka, M., Shimasaki, S. \& Ling, N. (1989) An insulin-like growth factor-binding protein in ovarian follicular fluid blocks follicle-stimulating hormone-stimulated steroid production by ovarian granulosa cells. Endocrinology 125, 912-916.

Wallace, J.M. \& McNeilly, A.S. (1985) Increase in ovulation rate after treatment of ewes with bovine follicular fluid in the luteal phase of the oestrous cycle. $J$. Reprod. Fert. 73, 505-515.

Wallace, J.M., MeNeilly, A.S. \& Baird, D.T. (1985) Ovulation rate and embryo survival in Damline ewes after treatment with bovine follicular fluid in the luteal phase of the oestrous cycle. J. Reprod. Fert. 75, 101-109.

Wallace, J.M., McNeilly, A.S. \& Tsonis, C.G. (1986) Effect of bovine follicular fluid (bFF) treatment throughout the luteal phase on LH, FSH and ovarian follicular development in the ewe. Ann. Conf. Soc. Stud. Fertil. Aberdeen, July, abstr. 79.

Ying, S.-Y., Becker, A., Ling, N., Ueno, N. \& Guillemin, R. (1986) Inhibin and beta type transforming growth factor (TGF $\beta$ ) have opposite modulating effects on the follicle stimulating hormone (FSH)-induced aromatase activity of cultured rat granulosa cells. Biochem. Biophys. Res. Commun. 136, 969-975.

Received 6 August 1990 